\title{
KOMPARASI HAK ASUH DAN HAK NAFKAH ANAK DALAM PUTUSAN- PUTUSAN PERCERAIAN DI PENGADILAN NEGERI DAN PENGADILAN AGAMA KOTA SURAKARTA
}

\author{
Anjar S C Nugraheni, Diana Tantri C,Zeni Luthfiyah \\ Fakultas Hukum Universitas Sebelas Maret \\ Email :anugrah@gmail.com; dianatantri@yahoo.com; zenilutfiyah@yahoo.com
}

\begin{abstract}
The high number of divorce in every year creates concern toward the children's rights whose have parents divorce. Therefore, the writers did the research in order to identify the legal protection of children's rights post parents divorce either for rights to rearing and rights to basic necessities. The research is involved into sociological research. The primary data was obtained through interview and the secondary data was coming from literature study from judge's verdict in District court of Surakarta (either for general District court or religion District court). Technical analysis uses qualitative data specially using deductive method. This research shows that most of all the verdicts (judge's decision), more than 75\%, does not have any substantial decision regarding rights to rearing and rights to basic necessities (in both district court-general District court and religion District court). Based on this result, it means that the legal protection for the children's who experience parents divorce is at very minimum legal protection for their rights. The differences of legal protection, research by the writers between both district court, are in religion District court, the underwriter for rearing is given to the mother if the children are below 12 years old (mumayiz) and beyond 12 years old, the children could choose the underwriter is (until he or she is in the mature age-21 years old). Meanwhile, in general District court, there are no clauses regarding what and who are the underwriter, there is no mumayiz term including the differences uses of mature age between 18 years old or 21 years old.
\end{abstract}

Keywords: divorce, rights to rearing, rights to basic necessities, age limit.

\begin{abstract}
Abstrak
Semakin tingginya angka perceraian setiap tahunmemunculkan keprihatinan penulis tentang nasib anakanak yang orangtuanya mengalami perceraian. Oleh karena itu penulis melakukan penelitian dengan tujuanmengidentifikasi perlindungan hukum terhadap hak-hak anak pasca perceraian kedua orangtuanya baik hak asuh maupun hak nafkah anak. Penelitian ini termasuk penelitian sosiologis. Data primer diperoleh melalui wawancara dan data sekunder diperoleh melalui studi pustaka putusan-putusan hakim di PN dan PA Kota Surakarta. Teknik analisis menggunakan analisis data kualitatif khususnya dengan metode deduktif. Hasil penelitian menunjukkan sebagian besar putusan $( \pm 75 \%)$ tidak mengandung amar putusan tentang hak asuh dan hak nafkah anak baik putusan perceraian di PN maupun PA.Hal ini berarti masih kurangnya perlindungan hokum terhadap hak-hak anak pasca perceraian kedua orangtuanya.Perbedaan perlindungan hukum yang diidentifikasi penulisantara di PA dan PN ialah jika di PA, kuasa hak asuh diseyogyakan adalah ibu jika anak belum berumur 12 tahun (mumayiz) dan setelah berumur lebih dari 12 tahun, anak dapat memilih siapa yang memegang hak asuh atas dirinya serta umur kedewasaan adalah 21 tahun. Sementara di PN, tidak ada ketentuan yang jelas siapa kuasa hak asuh, tidak dikenal istilah mumayyiz dan umur kedewasaan ada yang menganggap sampai berumur 18 tahun tapi ada juga yang sampai berumur 21 tahun .
\end{abstract}

Kata kunci: Perceraian, hak asuh anak, hak nafkah anak, batas umur.

\section{A. Pendahuluan}

Meningkatnya angka perceraian di Indonesia khususnya kota Surakarta sangat signifikan. Trend yang terjadi di Indonesia menunjukkan angka perceraian yang semakin meningkat dari tahun ke tahun.Khusus di Kota Surakarta, angka perceraian mengalami peningkatan sekitar $20 \%$ $30 \%$ setiap tahun. Data yang didapat dari PN Solo menyatakan jumlah gugatan perceraian yang masuk pada tahun 2010 sebanyak 83 kasus, 
tahun 2011 sebanyak 100 kasus dan tahun 2012 sebanyak 190 kasus (Laporan tahunan PN Solo). Data Januari hingga September 2013, kasus perceraian di PN Kota Solo mencapai 110 kasus. Sementara data yang dirilis PA Solo pada 2010 lalu jumlah angka perceraian di Kota Solo sebanyak 590 kasus. Pada tahun 2011 meningkat menjadi 666 kasus. Sementara pada tahun 2012 mencapai 733 kasus (Laporan tahunan PA Solo).

Perceraian kedua orang tua tanpa diikuti kepastian hukum tentang hak asuh dan hak nafkah untuk anak berpotensi menghilangkan hak-hak anak. Kepastian hukum tersebut berbentuk suatu putusan hakim sehingga apabila ada pihak yang tidak melaksanakan dengan baik, dapat dieksekusi. Namun apabila tidak ada putusan hakim dan hanya berbentuk kesepakatan antar pihak maka rawan konflik dalam bentuk pengabaian/penelantaran hak-hak anak.Hal inidapat menyebabkan jumlah anak yang bermasalah atau bahkan anak berhadapan dengan hukum $(\mathrm{ABH})$ meningkat.

Sebagai perbandingan dapat dipaparkan di sini hasil penelitian tentang hak nafkah istri setelah perceraian yang pernah dilaksanakan oleh tim peneliti dari Pusat Penelitian dan Pengembangan Gender (P3G) UNS ( 38: 2005). Tidak banyak perempuan yang mau menuntut haknya pasca perceraian, karena ketidaktahuan, dan juga besarnya energi yang dibutuhkan untuk mengurus hak nafkah mereka. Kontrol wanita bekerja terhadap pengaturan nafkah pasca perceraian sangat rendah atau tidak begitu mempedulikan. Kondisi ini disebabkan karena:

1. Merasa mampu mencari nafkah sendiri;

2. Malu kalau harus meminta-minta pada mantan suami;

3. Menghindari terjadinya konflik dengan isteri atau keluarga mantan suami dan/atau;

4. Enggan mengurus melalui pengadilan karena prosedur yang panjang dan biaya yang besar.

Mencermati hasil penelitian di atas maka prediksi keadaan/kondisi hak-hak anak pasca perceraian, tidak jauh berbeda.Jika menuntut haknya saja, perempuan terkendala, apalagi menuntut hak-hak anaknya.

Keprihatinan mengenai nasib (hak-hak) anak pasca perceraian kedua orangtua terutama mengenai pembagian hak asuh anak bukan hanya ada pada peneliti, tapi dalam skala dunia, hal ini juga menjadi permasalahan yang sangat serius ketika nasib anak-anak sebagai generasi penerus bangsa, dipertaruhkan. Di International Journal of Law, Policy and the Family, Novales dalam artikelnya yang berjudul The equality rights of parents and the protection of the best interests of the child after partnership breakdown in Spain (2012: 378-400) menulis:

"In a society in which the power relations between couples and the sharing of domestic tasks are unequal, the application of shared custody will not be exempt from tensions and contradictions. However, above all, the needs of children must be given priority and this requires that agreements reached by parents must be flexible and able to guarantee the rights and well-being of their children. This necessitates efforts to develop clear and reliable criteria for use at the point of implementing the new legislation relating to shared custody"

Anak adalah masa depan bangsa. Dalam kaitannya dengan kenyataan bahwa anak adalah asset bangsa, penerus cita-cita dan ditangannyalah terletak masa depan bangsa, maka keadaan sebagaimana di atas, tentu tidak bisa dibiarkan. Potensi anak menjadi terabaikan karena perceraian kedua orangtua harus dicegah dan diminimalisir.

Oleh karena itu melalui artikel ini, penulis mempublikasikan hasil penelitian yang berupa komparasi putusan-putusan perceraian di PN dan PA Kota Surakarta. Implikasi dari penelitian ini,penulis ingin membangkitkan kepedulian yang lebih besar dari semua elemen masyarakat dan mengarusutamakan pentingnya kepastian hukum hak-hak anak (korban perceraian kedua orangtua) sebagai generasi penerus bangsa.

\section{B. Metode Penelitian}

Penelitian ini termasuk penelitian eksplanatoris sosiologis. Data primer diperoleh melalui wawancara dengan panitera dan hakim-hakim dari Pengadilan Negeri dan Pengadilan Agama Kota Surakartaserta FGD yang dilakukan dengan mengundang Advokat, LSM dan dosen-dosen Fakultas Hukum UNS dari bagian Perdata, Acara dan Humas.Data sekunder diperoleh melalui studi pustakaperaturan perundang-undangan terkait perceraian, peraturan perundang-undangan terkait hak-hak anak, angka statistic perceraian, putusanputusan perceraian dari tahun 2010 sampai 2012 di Pengadilan Negeri (30 putusan) dan Pengadilan Agama Kota Surakarta (75 putusan), Yurisprudensi MA terkait perceraian, kasus-kasus perceraian yang melibatkan anak di media massa.

Teknik cuplikan menggunakan purposive sampling sementara teknik analisis menggunakan analisis data kualitatif khususnya dengan metode deduktif. Untuk lebih menguji kebenaran dari data yang dikumpulkan supaya kesimpulan penelitian benar-benar sahih, digunakan validitas data model triangulasi data. 


\section{Hasil Penelitian dan Pembahasan}

Ketentuan yang mengatur tentang hak asuh dan hak nafkah anak dapat ditemukan dalam:

\section{UU Perkawinan Pasal 41jo Pasal $\mathbf{4 5}$}

"Akibat putusnya perkawinan karena perceraian ialah:

a. Baik ibuatau bapak tetap berkewajiban memelihara dan mendidik anak-anaknya, semata-mata berdasarkan kepentingan anak, bilamana ada perselisihan mengenai penguasaan anak-anak, Pengadilan memberi keputusan.

b. Bapak yang bertanggung jawab atas semua biaya pemeliharaan dan pendidikan yang diperlukan anak itu, bilaman bapak dalam kenyataannya tidak dapt memberi kewajiban tersebut pengadilan dapat menentukan bahwa ikut memikul biaya tersebut."

\section{PP No 9 Tahun 1975 Pasal 24 ayat (2)}

Selama berlangsungnya gugatan perceraian atas permohonan penggugat atau tergugat, Pengadilan dapat:Menentukan halhal yang perlu untuk menjamin pemeliharaan dan pendidikan anak

3. PP No 10 Tahun 1983 sebagaimana diubah dengan PP45tahun 1990Pasal8yang intinya:

Apabila perceraian terjadi atas kehendak Pegawai Negeri Sipil pria maka ia wajib menyerahkan sebagian gajinya untuk penghidupan bekas isteri dan anak-anaknya. (2) Pembagian gaji sebagaimana dimaksud dalam ayat (1) ialah sepertiga untuk Pegawai Negeri Sipil pria yang bersangkutan, sepertiga untuk bekas isterinya, dan sepertiga untuk anak atau anak-anaknya.

4. Kompilasi Hukum Islam/KHI (Inpres No 1 Tahun 1991) Pasal 105 jo Pasal 156

Dalam hal terjadinya perceraian :

a. Pemeliharaan anak yang belum mumayyiz atau belum berumur 12 tahun adalah hak ibunya; b. Pemeliharaan anak yang sudah mumayyiz diserahkan kepada anak untuk memilih diantara ayahatau ibunya sebagai pemegang hak pemeliharaannya;

c. biaya pemeliharaanditanggung olehayahnya.

Dari ketentuan-ketentuan hukum di atas, nyatalah bahwa ketentuan hak asuh anak paling jelas ada di $\mathrm{KHI}$ yang berlaku di PA, sementara pengaturan tentang hak nafkah yang paling konkrit ada di PP Nomor 10 tahun 1983 yang berlaku untuk PNS. Oleh karenanya saat hakim memutuskan suatu kasus perceraian, banyak faktor riel yang harus dipertimbangkan supaya putusannya membawa kemanfaatan bagi semua pihak.

Dalam artikel ini, hak asuh dan hak nafkah anak yang penulis titikberatkan karena penulis menafsirkan bahwa hak asuh dan hak nafkah anak merupakan hak anak yang paling mendasar.Dalam kata asuh tersebut menurut Kamus Besar Bahasa Indonesia (2008:118) terkandung kata menjaga (merawat dan mendidik), membimbing (melatih, membantu) dan memimpin (mengepalai, menyelenggarakan). Wujud konkrit dari hak-hak anak secara substansi dapat dipedomani dari Konvensi Hak Anak (convention on The rights Of The child) pada tanggal 20 November 1898 (telah diratifikasi melalui Keputusan Presiden (Keppres) Nomor 36 Tahun 1990 Tentang pengesahan convention on the rights of the child (konvensi tentang hak-hak anak). Dalam Konvensi tersebut disebutkan macam hak anak adalah: (1) Hak atas kelangsungan hidup, (2) Hak atas perlindungan, (3) Hak atas tumbuh kembang optimal, dan (4) Hak untuk berpartisipasi.

Hasil studi penulis terhadap putusanputusan perceraian di PN dan PA Surakarta dapat disajikan dalam bentuk tabel seperti di bawah ini:

Tabel1. Rekap Sampling Putusan-Putusan Perceraian Pengadilan NegeriSurakarta Tahun 2010-2012

\begin{tabular}{|c|c|c|c|c|c|c|c|c|}
\hline \multirow{2}{*}{ No. } & \multirow{2}{*}{$\begin{array}{l}\text { Pengadilan } \\
\text { dan tahun }\end{array}$} & \multicolumn{2}{|c|}{ Melibatkan anak } & \multicolumn{2}{|c|}{ Petitum } & \multicolumn{2}{|c|}{ Amar } & \multirow{2}{*}{$\begin{array}{l}\text { Putusan } \\
\text { Verstek }\end{array}$} \\
\hline & & anak & $<18$ th & $\mathrm{HA}$ & $\mathrm{HN}$ & $\mathrm{HA}$ & $\mathrm{HN}$ & \\
\hline 1 & 2 & 3 & 4 & 5 & 6 & 7 & 8 & 9 \\
\hline 1 & PN 2010 & $90 \%$ & $90 \%$ & $20 \%$ & $10 \%$ & $20 \%$ & $10 \%$ & $0 \%$ \\
\hline 2 & PN 2011 & $80 \%$ & $80 \%$ & $40 \%$ & $20 \%$ & $40 \%$ & $20 \%$ & $10 \%$ \\
\hline 3 & PN 2012 & $90 \%$ & $80 \%$ & $40 \%$ & $10 \%$ & $40 \%$ & $10 \%$ & $10 \%$ \\
\hline
\end{tabular}


Berdasar tabel di atas dapat dianalisis bahwa pada tahun 2010 dari 10 kasus perceraian di PN yang menjadi sample, 9 kasus melibatkan anak sebagai hasil dari perkawinan kedua orang tuanya (90\%). Dari ke 9 kasus tersebut, semuanya ada anak yang masih di bawah umur kedewasaan. Putusan hakim yang menyebutkan tentang hak asuh ada $2(20 \%)$ sementara putusan hakim tentang hak nafkah anak hanya ada 1 (10\%). Sementara yang 7 kasus (70\%) merupakan cerai murni. Tidak ada kasus verstek dalam arti semua kasus diperiksa dan diputus dengan kehadiran kedua belah pihak baik penggugat ataupun tergugat.

Berdasar tabel di atas dapat dianalisis bahwa pada tahun 2011 dari 10 kasus perceraiandi $P N$ yangmenjadi sample, 8 kasus melibatkan anak sebagai hasil dari perkawinan kedua orang tuanya (80\%). Dari ke 8 kasus tersebut, semuanya ada anak yang masih di bawah umur kedewasaan.
Putusan hakim yang menyebutkan tentang hak asuh ada 4 (40\%) sementara putusan hakim tentang hak nafkah anak ada 2 (20\%). Sementara yang 6 kasus (60\%) merupakan cerai murni. Putusan verstek hanya ada 1 (10\%).

Berdasar tabel di atas dapat dianalisis bahwa pada tahun 2012 dari 10 kasus perceraiandi PN yang menjadi sample, 9 kasus melibatkan anak sebagai hasil dari perkawinan kedua orang tuanya (90\%). Dari ke 9 kasus tersebut, ada 8 kasus (80\%) yang melibatkan anak yang masih di bawah umur kedewasaan.Putusan hakim yang menyebutkan tentang hak asuh ada 4 (40\%) sementara putusan hakim tentang hak nafkah anak ada 1 (10\%). Sementara yang 6 kasus (60\%) merupakan cerai murni. Putusan verstek hanya ada 1 (10\%).

Sementara untuk tabulasi putusanputusan perceraian di PA Surakarta dapat disajikan dalam tabel di bawah ini:

Tabel 2. Rekap Sampling Putusan-Putusan Perceraian Pengadilan Agama Surakarta Tahun 2010-2012

\begin{tabular}{|c|c|c|c|c|c|c|c|c|c|}
\hline \multirow{2}{*}{ No. } & \multirow{2}{*}{$\begin{array}{l}\text { Pengadilan } \\
\text { dan tahun }\end{array}$} & \multicolumn{3}{|c|}{ Melibatkan anak } & \multicolumn{2}{|c|}{ Petitum } & \multicolumn{2}{|c|}{ Amar } & \multirow{2}{*}{$\begin{array}{l}\text { Putusan } \\
\text { Verstek }\end{array}$} \\
\hline & & anak & $<21$ th & $<12$ th & $\mathrm{HA}$ & $\mathrm{HN}$ & $\mathrm{HA}$ & $\mathrm{HN}$ & \\
\hline 1 & 2 & 3 & 4 & 5 & 6 & 7 & 8 & 9 & \\
\hline 1 & PA 2010 & $76 \%$ & $76 \%$ & $60 \%$ & $0 \%$ & $0 \%$ & $0 \%$ & $0 \%$ & $61 \%$ \\
\hline 2 & PA 2011 & $80 \%$ & $80 \%$ & $72 \%$ & $4 \%$ & $20 \%$ & $4 \%$ & $20 \%$ & $68 \%$ \\
\hline 3 & PA 2012 & $72 \%$ & $72 \%$ & $64 \%$ & $8 \%$ & $8 \%$ & $4 \%$ & $8 \%$ & $64 \%$ \\
\hline
\end{tabular}

Berdasar tabel di atas dapat dianalisis bahwa pada tahun 2010 dari 25 putusan perceraian di PA yang dijadikan sample, 19 kasus melibatkan anak sebagai hasil dari perkawinan kedua orang tuanya (76\%). Dari ke 19 kasus tersebut, 19 kasus (76\%) yang melibatkan anak yang masih di bawah umur kedewasaan dan 15 (60\%) kasus yang melibatkan anak di bawah umur 12 tahun( mumayiz). Putusan hakim yang menyebutkan tentang hak asuh ada $0(0 \%)$ sementara putusan hakim tentang hak nafkah anak juga $0(0 \%)$. Sementara semua kasus $(100 \%)$ merupakan cerai murni. Putusan verstek ada 17 putusan (61\%).

Berdasar tabel di atas dapat dianalisis bahwa pada tahun 2011 dari 25 putusan perceraian di PA yang menjadi sample, 20 kasus melibatkan anak sebagai hasil dari perkawinan kedua orang tuanya (80\%). Dari ke 20 kasus tersebut, semua kasus (80\%) yang melibatkan anak yang masih di bawah umur kedewasaan dan 18 (72\%) kasus yang melibatkan anak di bawah umur 12 tahun( mumayiz). Putusan hakim yang menyebutkan tentang hak asuh ada 1 (4\%) sementara putusan hakim tentang hak nafkah anak juga 5 (20\%). Sementara 20 kasus (80\%) merupakan cerai murni. Putusan verstek ada 17 putusan (68\%).

Berdasar tabel di atas dapat dianalisis bahwa pada tahun 2012 dari 25 putusan perceraian di PA yang dijadikan sample, 18 kasus melibatkan anak sebagai hasil dari perkawinan kedua orang tuanya (72\%). Dari ke 18 kasus tersebut, semua kasus (72\%) yang melibatkan anak yang masih di bawah umur kedewasaan dan 16 (64\%) kasus yang melibatkan anak di bawah umur 12 tahun( mumayiz). Gugatan tentang hak asuh anak 
sebenarnya ada 2 kasus ( $8 \%$ ) tapi putusan hakim yang menyebutkan tentang hak asuh ada $1(4 \%)$ sementara gugatan tentang hak nafkah anak ada 2 (8\%) dan putusan hakim tentang hak nafkah anak juga ada 2 (8\%). Sementara 16 kasus (64\%) merupakan cerai murni. Putusan verstek ada 16 putusan (64 $\%)$.

Hasil dari tabulasi putusan-putusan perceraian di atas dapat dianalisis sebagai berikut:

1. Sebagian besar cerai murni dalam arti tidak ada amar tentang hak asuh dan hak nafkah anak. Hal ini disebabkan oleh 2 hal:

a. Dahulu kasus perceraian tidak boleh digabung dengan pembagian harta bersama. Hal ini didasarkan pada yurisprudensi-yurisprudensi sebagaimana disebutkan di bawah ini:

1) Yurisprudensi MARI No. $913 \mathrm{~K} /$ SIP/1982 tanggal 21 Mei 1983 yang menyebutkan:"Gugatan mengenai perceraian tidak dapat digabungkan dengan gugatan mengenai harta benda perkawinan";

2) Yurisprudensi MARI No. $2205 \mathrm{~K} /$ Pdt/1981 tanggal 30 Juni 1984 yang menyebutkan: "Tidak dibenarkan menggabungkan gugatan perceraian dengan pembagian harta bersama";

3) Yurisprudensi MARI No. 1020K/ Pdt/1986 tanggal 29 September 1987 yang menyebutkan: "Pembagian harta bersama tidak dapat diajukan bersamasama dengan gugatan perceraian";

Sejak tahun 1989 yaitu dengan dikeluarkannya UndangUndang Nomor 7 tahun 1989 Tentang Peradilan Agama, ada pemahaman baru di kalangan hakim sebagaimana termanifestasi dalam Putusan 278/Pdt.G/2012/ PA. Gs (gresik). Dalam putusan tersebut terdapat pertimbangan dari majelis hakim yang berbunyi sebagai berikut:
Menimbang, terhadap eksepsi a quo Majelis berpendapat bahwa masalah kumulasigugatan (samenvoeging van vordering) telah diatur dalam Undang-Undang Nomor 7 Tahun1989 Pasal 66 ayat (5) yang memberikan pengertian secara tegas tentang kebolehan bagisuami yang mengajukan permohonan cerai talak sekaligus permohonan pembagian hartabersama . Tujuannya untuk menyederhanakan proses (procesuel doelmatig) danmenghindarkan putusan yang saling bertentangan, dengan model ini maka prosesnya menjadisederhana, biayanya menjadi lebih murah, tidak banyak waktu dan tenaga yang dibutuhkan.Pasal ini paralel dengan azas peradilan sederhana, cepat dan biaya ringan untuk memberikankemudahan dan pelayanan yang baik kepada masyarakat pencari keadilan. Untuk mewujudkanazas ini maka sebagaimana ketentuan Pasal 58 ayat (2) Undang-Undang Nomor 7 Tahun 1989,menyatakan "pengadilan membantu para pencari keadilan dan berusaha sekeras-kerasnyauntuk mengatasi segala rintangan untuk tercapainya peradilan yang sederhana, cepat danbiaya ringan" (vide : Pasal 4 ayat (2) Undang-undang Nomor 4 Tahun 2004 tentangKekuasaan Kehakiman);

Peneliti sangat setuju dengan pendapat ini. Sebagaimana diketahui bahwa akibat suatu perkawinan menurut Pasal 41 UUP jo Pasal 156 $\mathrm{KHI}$, ada 3 yaitu:

1) Status pihak yang melaksanakan perkawinan

2) Anak yang dihasilkan dari perkawinan tersebut

3) Harta perkawinan yang didapat selama perkawinan

Dalam suatu perkawinan ketiga hal tersebut biasanya muncul.Dapat dibuktikan dalam tabel di atas bahwa perceraian di PN yang melibatkan anak, prosentasenya berkisar $80 \%$ - 
$90 \%$, sementara di PA ada $64 \%$ $80 \%$. Jika kemudian saat pemutusan perkawinan/perceraian hanya hal pertama yang diputus sementara hal kedua dan ketiga tidak diputuskan bahkan tidak disinggung, ini jelas akan menimbulkan kasus yang belum tuntas. Hal ini berlawanan dengan asas "sederhana, cepat, dan biaya murah".

b. Jika dalam petitum tidak ada permohonan tentang hak asuh dan hak nafkah anak maka hakim juga tidak bisa berbuat banyak karena asas dalam acara perdata: hakim bersikap pasif (verhandlungs maxime) dan ultra petita. Asas hakim pasif artinya bahwa seorang hakim hanya diperkenankan memeriksa dan memutus segala sesuatu yang dituntut oleh para pihak. Sementara asas ultra petita berarti seorang hakim tidak diperkenankan memeriksa dan memutus lebih dari pada yang dituntut (Th. Kussunaryatun, 1993:10).

Adanya kedua asas tersebut menyebabkan amar putusan hakim hanya sebatas apa yang dituntut para pihak. Dalam penelitian yang dilakukan penulis, jika para pihak tidak memohonkan hak asuh anak dan hak nafkah anak maka hakim tidak bisa memutus tentang hal tersebut dalam amar putusannya. Saat penulis tanyakan dalam wawancara ke panitera dan para hakim baik di PN maupun PA Surakarta, mendapat jawaban yang sama yaitu jika tidak dituntut para pihak berarti tidak dipersengketakan para pihak. Dengan kata lain berarti sudahada kesepakatan para pihak tentang hak asuh dan hak nafkah anak dalam kasus perceraian tersebut. Hal ini muncul dari anggapan para hakim maupun seperti yang dinyatakan oleh para pihak atau kuasa hukumnya jika hakim menanyakan hal ini.

Menurut penulis, hal di atas terlalu menyederhanakan masalah. Banyak kasus terjadi, saat orangtua menghadapi masalah, mereka tidak memperdulikan lagi nasib (baca: hak) anak-anaknya karena mereka terlalu sibuk, sedih, marah, dan bingung memikirkan nasibnya sendiri. Atau dalam kasus lain, setelah putusan hakim, kesepakatan di antara pihak tidak dijalankan karena berbagai sebab. Pemegang/ kuasa hak asuh melalaikan kewajibannya karena misalnya sudah bertemu dengan pria atau wanita lain, sudah mempunyai anak lagi dengan pasangan yang baru, terlalu sibuk mencari penghasilan dan lain-lain. Sementara pihak yang seharusnya menanggung nafkah anak, juga kemudian tidak melaksanakan kewajibannya karena sudah tidak ada daya tekan lagi, lupa, sibuk dengan kehidupannya yang sekarang, dan lain-lain.Walaupun juga banyak bapak ibu yang sudah bercerai tapi tetap menjalankan kewajibannya secara baik kepada anak-anaknya meskipun sudah berpisah dan tidak mendiami rumah yang sama.

Apapun keadaan yang penulis paparkan di atas, menurut penulis akantetap lebih baik jika kesepakatan di antara para pihak tersebut dimuat dalam putusan hakim. Putusan hakim yang sudah mempunyai kekuatan hukum tetap (in kracht van gewijsde) mempunyaikekuatan mengikat, kekuatan pembuktian, dan kekuatan eksekutorial. Jika para pihak tidak melaksanakan halhal yang sudah disepakati maka dengan adanya putusan hakim yang sudah mempunyai kekuatan hukum tetap tersebut, dapat diajukan permohonan eksekusi oleh salah satu pihak.

Menurut hasil wawancara dengan para hakim bahwa sebenarnya walaupun asasnya hakim bersikap pasif namun dalam persidangan ia harus bersikap aktif. Dalam hal ini hakim sebenarnya bisa mengingatkan para pihak tentang hak asuh dan hak nafkah anak saat proses mediasi.Jika sebelumnya dalam petitum perceraian hanya 
memuat tuntutan tentang putusnya perkawinan maka para pihak kemudian dapat mengubah atau menambah gugatan tersebut. Jika pihak yang satunya yang ingin memasukkan gugatan tentang hak asuh dan hak nafkah anak maka dapat mengajukan gugat balik atau rekonvensi.Jika sudah telanjur ada putusan hakim yang in kracht tentang pemutusan perkawinan maka para pihak dapat mengajukan gugatan baru tentang hak asuh dan hak nafkah anak.

Alternatif-alternatif solusi di atas, menurut penulis tetap menunda permasalahan yang sebenarnya bisa diselesaikan dalam satu putusan.Namun hal ini tetap merupakan pilihan yang harus dipilih oleh para pihak. Jika mereka memilih untuk memasukkan hak asuh dan hak nafkah anak dalam petitum dan jika ini kemudian menjadi sengketa atau alasan pihak lain untuk mengulur-ulur waktu, maka kasus bisa berlangsung lama sebagaimana kasus perceraian antara Ahmad Dhani dan Maia Estianti yang di dalamnya ada perebutan perebutan hak asuh anak yang berlangsung selama 5 tahun yaitu dari tahun 2008 sampai 2013 dengan akhir yang berupa putusan peninjauan kembali yang memuat amar putusan bahwa karena anak yang diperebutkan sudah berumur 12 tahun ke atas maka diserahkan kepada si anak untuk memilih siapa atau orang tua mana yang akan memegang hak asuhnya.

2. Sebagian merupakan putusan verstek yaitu suatu proses beracara di pengadilan yang selama prosesnya tanpa pernah dihadiri satu kalipun oleh Tergugat/ Termohon. Hal ini dikarenakan pihak Tergugat/Termohon tidak merasa perlu untuk menghadiri persidangan karena merasa tidak ada kepentingannya yang terancam.

Mengapa kepentingan tergugat/ termohon tidak terancam?Hal ini dapat dijelaskan sebagai berikut. Selama petitum hanya berisi tuntutan kepada hakim untuk menyatakan bahwa perkawinan antara pihak putus dengan segala akibat hukumnya, maka tidak ada yang perlu dikhawatirkan oleh pihak lain kecuali jika ia tidak menghendaki pemutusan perkawinan tersebut. Akan lain halnya jika petitum juga berisi selain pemutusan perkawinan yaitu hak asuh dan hak nafkah anak serta pembagian harta gono gini maka tergugat/termohon akan merasa perlu untuk menghadiri persidangan guna mempertahankan hak-haknya. Selain itu yang juga harus dicermati, untuk PA yang berpedoman kepada $\mathrm{KHI}$, hak asuh jelas diberikan ke ibu jika anak belum berumur 12 tahun, tetapi di PN, ketentuan ini tidak ada, sehingga jika angka verstek di PN lebih rendah dari PA, mungkin dapat dijelaskan dengan alasan ini.Hanya merupakan kebiasaan jika hak asuh untuk anak diberikan ke ibu walau ini juga tidak mutlak.

Hasil wawancara dengan panitera dan hakim PN dan PA menyatakan bahwa walaupun Tergugat/Termohon verstek, namun ada petitum dari Penggugat/ Pemohon tentang hak asuh dan/atau hak nafkah anak, maka tetap akan dipertimbangkan oleh hakim.

Pertimbangan hakim tentang hak asuh anak terutama ditekankan pada kepentingan dan kemanfaatan anak. Walaupun peraturan perundangperundangan dan kebiasaan lebih condong memberikan hak asuh kepada ibu apalagi jika anak masih di bawah umur atau masih mumayyiz, tetapi para hakim dari PN dan PA menyatakan hal yang sama bahwa ketentuan atau kebiasaan tersebut tidak serta merta diterapkan. Hak asuh anak dapat diserahkan pada bapak jika ibu mempunyai perangai, moral atau tingkah laku yang buruk, seperti ibu berprofesi sebagai Pekerja Seks Komersial (PSK), ibu selingkuh atau mempunyai Pria Idaman Lain (PIL) yang menyebabkan suami mengajukan permohonan talak/gugat cerai.

Yang menjadi perhatian penulis dalam hak asuh anak adalah adanya 
perbedaan antara ketentuan di PN dan PA tentang pemegang/kuasa hak asuh anak dan batas umur anak yang harus diserahkan hak asuhnya pada ibu. Di PA dengan berdasar pada Pasal $156 \mathrm{KHI}$, maka hak asuh anak ada pada ibu jika anak belum berumur 12 tahun. Namun di $P N$, ketentuan seperti ini tidak ditemui.Akibatnya para hakim mempunyai penafsiran sendiri, ada yang menyebut umur bawah 5 (lima) tahun (balita), namun juga ada yang menyebut batas umurnya adalah 8 tahun sesuai aturan dalam Hukum Pidana. Hal ini dapat menyebabkan berkurangnya kepastian hukum. Oleh karena itu menurut penulis hendaknya dapat ditentukan atau disepakati batas umur yang sama untuk semua hakim di pengadilan manapun tentang batas umur anak yang hak asuhnya diberikan pada ibu.

Sementara untuk hak nafkah anak, berdasar hasil wawancara, pertimbangan hakim ditekankan pada kebutuhan anak, penghasilan bapak dan kesanggupan si bapak untuk memberikan nafkah pada si anak. Walaupun si bapak berpenghasilan besar namun jika kesanggupannya (baca: kerelaannya) hanya untuk jumlah tertentu, maka berdasar hak ex officioyang terwujud dalam petitum subsider, hakim akan memutus besaran nafkah anak yang disesuaikan dengan kesanggupan tadi. Argumentasi hakim di sini adalah daripada diputuskan dalam jumlah yang tinggi tapi bapak tidak melaksanakan putusan tadi maka lebih baik diputus dalam jumlah yang tidak terlalu jauh dari kesanggupan si bapak supaya bapak mematuhi putusan hakim.

Dalam hal sampai kapan pemberian hak nafkah anak, penulis mencermati bahwa ada ketidaksamaan dalam putusan-putusan hakim PN. Ada yang memutus sampai umur 21 tahun tapi juga ada yang memutus hanya sampai 18 tahun bahkan juga ada yang memutus sampai anak dewasa.Sementara untuk di PA, pemberian hak nafkah anak sampai anak berumur 21 tahun sesuai
$\mathrm{KHI}$ atau sampai anak tersebut dewasa. Adanya perbedaan ini juga berakibat pada kurangnya kepastian hukum. Oleh karenanya penulis juga menseyogyakan hendaknya dapat ditentukan atau disepakati batas umur yang sama untuk semua hakim baik di PA maupun PN manapun tentang batas umur anak yang masih berhak untuk mendapat nafkah dari kedua orangtuanya.

\section{d. Simpulan}

Simpulan yang bisa ditarik penulis dari penelitian di atas adalah:

1. Sebagian besar putusan ( $\pm 75 \%)$ tidak mengandung amar putusan tentang hak asuh dan hak nafkah anak baik putusan perceraian di PN maupun PA yang berarti perlindungan hukum terhadap hak-hak anak yang orangtuanya mengalami perceraian, masih kurang. Tidak adanya amar putusan tersebut karena dahulu ada yurisprudensi yang melarang penggabungan gugatan dalam suatu kasus perceraian dan adanya asas dalam acara perdata yaitu asas hakim pasif dan asas ultra petita.sehingga apabila dalam petitum tidak dimohonkan para pihak tentang hak asuh dan hak nafkah anak, hakim juga tidak bisa memberi amar putusannya.

2. Perbedaan yang diidentifikasi penulis tentang perlindungan hukum anak terutama menyangkut hakasuh dan hak nafkahnya antara putusan di PN dan PA Kota Surakarta adalah tentang subjek pemegang/kuasa hak asuh anak, ketentuan batas umur anak yang ditentukan pemegang/kuasa hak asuhnya dan batas umur kedewasaan anak. Di PA, pemegang/kuasa hak asuh diseyogyakan adalah ibu jika anak belum berumur 12 tahun (mumayiz) dan setelah berumur lebih dari 12 tahun, anak dapat memilih siapa yang memegang hak asuh atas dirinya serta umur kedewasaan adalah 21 tahun sebagaimana ketentuan di KHI. Sementara di PN, tidak ada aturan yang jelas tentang siapa pemegang/kuasa hak asuh bagi anak yang belum dewasa, tidak dikenal istilah mumayiz dan umur kedewasaan ada yang menganggap sampai umur 18 tahun tapi ada juga hakim yang menganggap sampai berumur 21 tahun. 


\section{E. Saran}

1. Para pihak hendaknya tetap memasukkan petitum tentang hak asuh dan hak nafkah anak guna menjamin kepastian hukum tentang hak-hak anak pasca perceraian kedua orang tua baik ada sengketa ataupun tidak.Dengan demikian hakim juga dapat mempertimbangkannya dan memuatnya dalam amar putusan karena suatu putusan hakim yang mempunyai kekuatan hukum tetap mempunyai kekuatan eksekutorial.

2. Para hakim di PA dan PN seyogyanya sepakat atau dapat merujuk pada satu ketentuan tentang batas seorang anak dapat memilih sendiri siapa yang memegang hak asuhnya dan batas umur sampai kapan seorang anak masih dapat menuntut hak nafkah dari orangtuanya.

\section{F. Persantunan}

Atas selesainya artikel dan laporan penelitian dari penulis, penulis dan tim mengucapkan terimakasih yang tak terhingga kepada ketua, para hakim, dan panitera serta staf administrasi di PN dan PA Kota Surakarta. Terimakasih penulis juga kepada teman-teman dosen, advokat, LSM, keluarga dan para pihak yang tidak dapat penulis sebutkan satu persatu dalam persantunan ini.

\section{daftar Pustaka}

A.A.G. Peters dan Koesriani Siswosoebroto. 1988. Hukum dan perkembangan Sosial. Buku Teks Sosiologi Hukum Buku I. Jakarta. Pustaka Sinar Harapan.

Burhan Ashshofa. 1996. Metode penelitian Hukum. Jakarta: PT. Rineka Cipta

Burhan Bungin. 2008. Analisis Data Penelitian Kualitatif. Jakarta: PT Raja Grafindo Persada

Djaja S. Meliala. 2007. perkembangan Hukum perdata tentang Orang dan Keluarga. Edisi revisi. Bandung: CV Nuansa Aulia.

H.B. Sutopo. 2002. pengantar penelitian Kualitatif. Surakarta: Pusat Penelitian (Puslit).

Henry Campbell Black. 1990. Black Law Dictionary- : ST Paul Nim West Publising.

Andy Hartanto. 2012. Hukum Harta Kekayaan perkawinan: Menurut Burgerlijke Wetboek dan UndangUndang perkawinan. Yogyakarta: Penerbit Laksbang Grafika.

M. Yahya Harahap. 2005. Hukum Acara Perdata. Jakarta. Sinar Grafika.

MG. Endang Sumiarni dan Chandera Halim. 2000. Perlindungan Hukum Terhadap Anak dalam Hukum Keluarga. Yogyakarta: Penerbit Universitas Atma Jaya.

Miles Mathew B. Huberman, A. 1992. Analisis Data Kualitatif (Buku SumberTentang Metode-metode Baru) Terjemahan Tjetjep rohendi rohidi, Jakarta: UI - Press

Mohd. Idris Ramulyo. 2006. Hukum Perkawinan, Hukum Kewarisan, Hukum Acara Peradilan Agama dan Zakat Menurut Hukum Islam. Jakarta: Sinar Grafika

Munir Fuady. 2005. perbandingan Hukum perdata. Bandung: PT. Citra Aditya Bakti.

Lexy J Moleong 2002. Metodologi penelitian Kualitatif. Bandung: PT Remaja Roda Karya.

Picont $\tilde{A}^{3}$ Novales, T.2012. The equality rights of parents and the protection of the best interests of the child after partnership breakdown in Spain International Journal of Law, policy and the Family, 26 (3).

Pusat Buku. 2008. Kamus Besar Bahasa Indonesia. Jakarta. Kementrian Pendidikan dan Kebudayaan

Robert K. Yin. 1996. Studi Kasus (Desain dan Metode). Jakarta: Rajawali Press

Sariyatun, Trisni Utami dan Al. Sentot Sudarwanto. 2005. Pemahaman Terhadap KDRT Dan Daya Kontrol Akses Perempuan Bekerja Terhadap Pengaturan Nafkah Pasca Perceraian (Studi Kasus Pada Keluarga Wanita Bekerja Pasca Perceraian di Surakarta). Laporan penelitian. Pusat Penelitian dan Pengembangan Gender (P3G) LPPM UNS. 
Satjipto Raharjo. 1986. Hukum dan Masyarakat. Bandung: PT. Angkasa.

2003. Sisi-sisi Lain dari Hukum di Indonesia, Jakarta : Kompas

Setiono. 2004. rule of Law (Supremasi Hukum). Surakarta: Magister Ilmu Hukum Program Pascasarjana Universitas Sebelas Maret.

Sudarsono.2005. Hukum perkawinan Nasional. Cetakan ke-3. Jakarta: PT Rineka Cipta

Taufiqurrohman Syahuri. 2013. Legislasi Hukum Perkawinan Di Indonesia: Pro Kontra Pembentukannya Hingga Putusan Mahkamah Konstitusi. Jakarta: Penerbit Kencana Prenada Media Group.

Th. Kussunaryatun. 1991. Hukum Acara Perdata. Surakarta: UNS Pers

Undang-Undang Dasar Republik Indonesia Tahun 1945

Kitab Undang-Undang Hukum Perdata

Undang-Undang No. 1 Tahun 1974 Tentang Perkawinan.

Undang-Undang No. 4 Tahun 1979 Tentang Kesejahteraan Anak

Undang-Undang No. 39 Tahun 1999 Tentang Hak Asasi Manusia

Undang-Undang No. 23 Tahun 2002 Tentang Perlindungan Anak

Undang-Undang No. 30 Tahun2004 Tentang Jabatan Notaris

70 Yustisia Vol.2 No.3 September - Desember 2013 Komparasi Hak Asuh dan Hak nafkah Anak ... 